\title{
FEMALE ENTREPRENEURSHIP IN RURAL AREAS IN THE ASPECT OF THE LABOR MARKET
}

\author{
Ewa Stawicka ${ }^{1}$, Phd; Maria Parlinska ${ }^{2}$, Prof. \\ 1, 2 Warsaw University of Life Sciences (WULS -SGGW)
}

\begin{abstract}
The article aims to assess the importance of undertaking entrepreneurial initiatives by women in rural areas. Authors review the literature on entrepreneurship and professional activity of women. Initiatives were examined within the framework of the use of aid programs for entrepreneurship. The study begins with a look at the development of entrepreneurship in the context of sustainable rural development. Then, the attitudes of women to undertaking economic activity were traced. The long-term changes concerning education and preparation of women in the professional market were verified. The article ends with reflections on the social and economic importance of undertaking entrepreneurial activities by women in rural areas, as well as finances and support for such initiatives.
\end{abstract}

Keywords: woman, rural areas, entrepreneurship, Poland.

JEL code: A13, Q18.

\section{Introduction}

In business management, the main goal of the effort is to achieve success understood as prosperity, success, or a successful outcome of implemented activities. Success then is the result of the entrepreneur's game for the effectiveness of the functioning of his enterprise. Success can be defined as the situation in which the company will bring the desired profits now and in the future, the quality of manufactured goods will be satisfactory, and the company, thanks to its good image, will be able to enjoy credibility and an established position on the market.

The concept of "entrepreneurship" was first introduced to the scientific literature by two French scientists Belidon and Say. Belidon described the first of them as an entrepreneurial buyer who, after purchasing material goods and work at a changing and uncertain price, sells the finished product at a fixed price, while Say pointed out a risk element in entrepreneurial activity. An enterprising businessman, placing his resources in an uncertain future, can gain a lot and a lot. Therefore, the entrepreneur invests his funds in the lower field for higher productivity and higher income. This definition was formulated almost two centuries ago, but by that time one single, binding definition of "entrepreneurship" had not been developed. Entrepreneurship in the field of economics is closely related to a man who over the centuries, through his activity and innovation, gave his shape and character. From a mathematical point of view, interest in the phenomenon of entrepreneurship was sinusoidal, from undervaluation in the times of classical or Marxist economics, ending with the focus on J. Schumpeter's theory which describes entrepreneurship as the driving force of the country. In the economy of the 21st century, the issue of entrepreneurship has become a social fact of increasing importance (Cumber C. J., et al., 2005)

Self-employment, which can be a good solution and professional opportunity for women in rural areas, gains importance in the development of entrepreneurship. The data of the Central Statistical Office show that there are more and more micro-enterprises in which women are among the owners and co-owners. When it comes to more stabilized entities (operating for more than 3.5 years), we also observe a dynamic increase in the percentage of enterprises run by women (from 2.9 to $3.8 \%$ ), but a much larger increase in this category applies companies owned by men (from 7.1 to $9.2 \%$ ). The results of PARP's research do not indicate for differences (PARP, 2014). In 2008, there were 928.5 thousand registered in rural areas economic entities, which constituted over $24 \%$ of all entities registered in the REGON number. Entrepreneurship indicator (measured by the number of business entities per 1000 inhabitants in 2008 was

1 Ewa Stawicka. Tel.: +48 22 5934182, ewa.stawicka.00@gmail.com,ewa_stawicka@sggw.edu.pl 
twice lower in rural areas than in cities and amounted to 62.5 (in the city - 121.5), 33.9 \% of all households operated in rural areas; they were on average from a larger number of people than in cities. Of nearly 1.6 million Polish farms, only every tenth can be considered competitive and can provide satisfactory income for farming families (Sikorska-Wolak I., et al., 2018).

Smaller and smaller part of the village inhabitants earns income from farm work. This process has significantly accelerated after accession EU, which clearly shows the direction of changes and the growing role of non-agricultural jobs in the employment structure of the rural population. Professional activation of women going towards running their own business is a phenomenon observed in Poland since the beginning of transformations to the market economy. The initiative of women living in the countryside shows some specific features depending on their family situation, age, education, and professional aspirations. It turns out that women are just as engaged in professional activities as men although they are much more absorbed in their work at home. However, they can reconcile these two spheres of activity. More and more women are interested in starting their own business. Such a change in the attitude of women, from passive to active, became possible thanks to political changes after 1989. Women living in the countryside more and more often decide to start their own business because they want to be independent and autonomous in making decisions, they want to pursue themselves in the professional field, they create jobs, they want to improve their and family's standard of living, they pay attention to the prognosis for their own economic activity, pay attention to the favorable policy of lending to small enterprises (FOCUS GROUP-CRSG, 2012; GUS, 2018).

Other factors encouraging women to decide starting their own business are willingness to be independent, pay appropriate to the amount of work, entrepreneurship, and creativity.

Our work illustrates the situation of active women living in rural areas. The subject of the study covered the social and professional characteristics of the entrepreneurial figure of a woman and mainly include:

1) social and professional characterological features (education, age, skills, and professional predispositions);

2) the type of economic initiatives undertaken by women;

3) obstacles to the development of business activities of enterprises run by women.

The article aims to assess entrepreneurship and prospects for women's professional development in rural areas in Poland. Indication of women's self-employment as one of the forms of supporting rural development. The research method is desk research, analysis of publications, reports, Statistics Poland data, and Eurostat.

\section{Research results and discussion}

According to Statistics Poland reports, the number of entrepreneurs in 2017 was 2.882 million. Most companies are located in the Mazowieckie Voivodeship, about $13 \%$ in the Slaskie Voivodeship and less than $11 \%$ in the Greater Poland Voivodeship. The smallest number of enterprises is located in the Opolskie Voivodeship - only $2 \%$ of all companies. In 2017, 2073.6 thousand were operating in Poland microenterprises (employing up to 9 people). This means an increase of $3.5 \%$ compared to the previous year and $20.8 \%$ compared to 2010. The financial result of micro-enterprises in 2017 was at the level of PLN 141.7 billion - i.e. an increase of $13.5 \%$ compared to 2016 and by $52.9 \%$ compared to 2010 . The vast majority of micro-enterprises in 2017 belonged to natural persons (89.3 \%, i.e. 1852.6 thousand entities). Legal entities and organizational units without legal personality constituted only $10.7 \%$ (221.1 thousand entities) (GUS, 2018). 
Polish Agency for Enterprise Development (PARP) data show that as many as 79 \% of Poles believe that starting their own business is a good idea to make a career. This is the second-best result in Europe, after the Netherlands, which achieved $81 \%$. The average score for Europe is $59 \%$. This is huge progress compared to 2016 when Poles in the vast majority perceived running the company only as a necessary way to earn. The number of entrepreneurs in Poland is increasing every year. The perception of the entrepreneur's image is also changing. According to the PARP Report (2018), over 68 \% of Poles believe that people who have set up their own companies and have been successful deserve respect and recognition. It should be noted that this is the first time since the beginning of GEM research in Poland when the result is at the level of other European countries and only slightly lower than in countries with the most developed economies.

In theory and practice, there is confirmation that being entrepreneurial is the sum of many factors. External factors that contribute to starting a business are national determinants and framework determinants. The most important are framework determinants that directly affect the economy by inhibiting or supporting it. Framework determinants include taxes and legal regulations, availability of capital (ease of obtaining funds for new and growing companies, public programs to support entrepreneurship, education and training, research and development, quality and the possibility of cooperation with subcontractors and various service providers, access to the Internet, telecommunications, electricity as well as cultural and social factors, aspects that support or discourage people from starting and developing a business. In the literature on the subject, factors affecting the level of women's entrepreneurship are more and more often indicated, research on this topic was conducted (Pujol M. E., 1992; Parlinska M., Sawicka J., 2004; Sawicka J., 2005; Wrzochalska A., 2013; Szepelska A., 2014; Krzyzanowska K., 2014).

In scientific research concerning women in rural areas, socio-geographical factors, family situation, age, level of education, gender, ethnicity, previous experience in self-employment, entrepreneurship were most often taken into account. The subject scope of the research is women's entrepreneurship, and among the basic features of entrepreneurial behavior can be indicated: knowledge, intelligence, courage, energy, ingenuity, risk-taking capacity, responsibility, as well as the ability to anticipate and self-control (European Parliament Resolution, 2012).

Rural women are increasingly seeking to work outside agriculture, are considering setting up their businesses or working in public benefit organizations, so they are an important target group for activities focused on the development of non-agricultural activities in rural areas. An important issue regarding women's entrepreneurship is other institutional factors, access to capital, childcare system, parental leave, costs of starting their own business (Moczydlowska J. M., 2017).

The professional activity of women, despite continuous development, is still at a lower level than in men. In 2017, the economic activity rate among men of working age was $80.2 \%$, for women it was at the level of $71.1 \%$. Among women older than 15 years, more than half are economically inactive, where among the men's community over 62 \% work, and only $34.9 \%$ are economically inactive. Most professionally inactive in both groups are persons under 20 and over 55. Family responsibilities are the main reason for the inactivity of women under 45 years of age. Among men, one of the most significant reasons is science activity. However, interestingly above the age of 25 , the most common reason for inactivity among men is an illness, there are far fewer such cases among women (Eurostat, Farmers in the EU-statistic, 2020).

Education is also an important aspect. Both women and men with higher education were more willing to work. The lowest professional activity is characteristic of basic education. Based on Statistics Poland data, nearly $45 \%$ of professionally active women have a university degree, where it is $27 \%$ among men 
(GUS, 2018). As for women's entrepreneurship, every third company is founded by a woman (33.4 \%), which is higher than the average in Europe (31\%). Still, women tend to run their businesses less often than men. On average, $5.4 \%$ of adult women are self-employed in Europe. The lowest entrepreneurship is shown by Italians and Bulgarian women (2.9 \%) as well as German and Slovenian women, among whom only every thirty adult woman runs her own business (3.3\%). Latvian (9.8\%), Estonian (9.7\%), Luxembourg (8.7\%) and Romanian (7.5 \%) perform best. Polish women are in seventh place in Europe, ex aequo with Greek women ( $6 \%$ of women are entrepreneurs). At the same time, along with the growing number of female entrepreneurs in Poland, the participation rate of Polish women is falling, which currently amounts to $48 \%$ among women in total, and $71.1 \%$ among women of working age. This is especially visible among women under 20 and aged 45-54 - in these age groups, the difference in the activity of women is the smallest (Eurostat, Farmers in the EU-statistic, 2020).

Due to different characteristics between men and women and their natural predispositions, it is obvious that employees, depending on gender, usually take on different professions or choose other industries in which they would like to work. The distinction between sex and professional activity is one of the most common. It also involves the natural social roles that people play in a generally accepted worldview, such as the fact that women usually take care of children on a larger scale. As a result, her work should usually be more flexible. A man is less often a guardian, so he may have more fixed working hours. It also affects the remuneration, which differs between employees in the same position - more often it is higher among men (PARP, 2011).

Family life is an important issue for most women. This is influenced by both biological considerations and stereotypes of society, which put a woman mainly as a guardian of the home. Career and development are secondary aspects. The main reason for such an order in many countries in the world is historical conditions. Initially, only men could work, women entered the labor market very slowly. It was only after World War II that the development of the economy caused a gradual increase in the economic activity of women. In 1950, the share of women in the total number of employees in Poland was at the level of $30.7 \%$, after 1970 it increased to over $40 \%$, at the beginning of the 90 s it exceeded $45 \%$, and since 2014 it has remained at the level of almost $49 \%$. The result of Poland's integration in the EU structures is beneficial changes and progress that has taken place in Polish agriculture. The Polish village is almost equal to rural areas in EU countries through, among others the introduction of new technologies and the use of modern agricultural production techniques. Due to the smaller involvement in agricultural work, a large number of women took up non-agricultural activities, and some women decided to run their farms. In recent years, there has been a growing interest in political decision-makers and scientific researchers in the subject of women in rural areas. The transformation of rural areas in the world is subject to constant influences and economic changes (Cumber C. J., et al., 2005; Istenic M. C., 2015; Wiest K., 2016; Varela-Candamio L., et al., 2018).

Restructuring, modernization, environmental changes, the development of modern information technologies, numerous migrations, and other social processes mean that the role and importance of women in rural areas are constantly changing (Wiest K., 2016; Alonso N., Trillo D., 2016; Yasaswini Y., et al., 2017; Mills M. B., 2016). Women play a key role in the rural economy of both developed and developing countries. In most developing countries, women in rural areas mainly participate in the cultivation and production of plants and animals, provide food to households, often engage in non-agricultural activities to diversify the means of subsistence for their families. They often have (also reproductive) functions in caring for children, the elderly, and the sick (Rural Women in a Changing World, 2008). 
The situation of women in rural areas is varied. This is mainly due to the diversity of their experiences in the context of the changing rural economy, e.g. their position in the household, local community, access to labor resources, technology, or information. Moreover, importantly, there are significant differences between women operating in rural areas, among others due to age, education, marital status, ethnicity, race, or religion. Women are increasingly exclusively or partly the owners of large corporations, enterprises, and farms. Importantly, women in the countryside more and more often and more willingly use modern information and communication technologies. Indeed, that the role of women and the information and communication tools and technologies they use are increasingly discussed in the literature, however, it is not comprehensively studied (Alonso N., Trillo D., 2016; Damesa T. E., Ogato G. S., 2016; FAO, 2019 ,).

Currently, the European Union places great emphasis on introducing activities aimed at bringing women together in the countryside. Noteworthy is, for example, the European Parliament Resolution of 5 April 2011 on the role of women in agriculture and rural areas (Official Journal EU C296E / 13 of 2 October 2012), where it is emphasized that, in the medium term, women's representation in political, economic and social bodies should be increased.

Interest in rural women is related to the new concept of development of non-urbanized areas adopted in the European Union and defined as a balanced and multifunctional model of rural development. According to this concept, the village next to the traditional agricultural function is to perform other important functions: recreational, residential, ecological and socio-cultural (Michalska S., 2013; Krzyzanowska K., 2014). This means the need to develop the service sector and the need for socio-professional activation of rural women, whose intellectual capital, and resources not yet fully utilized gain new value (Krzyzanowska N., 2013; Sawicka J., Lagoda J., 2015).

Activation of rural women should include, among others combining family and professional roles as well as participation in the social and political life of local communities and good and reliable communication (Parlinska M., Sawicka J., 2004; Krzyszkowski J., 2008; Wrzochalska A., 2013; Wojcieszak M., 2019).

Analyses of strategic documents at the global level show that women's potential is not sufficiently used in the policy conducted towards rural areas. The issues of women's activation, increasing their participation in the labor market, or in creating social capital are not sufficiently highlighted in development policy, and thus in rural development policy.

Women's economic empowerment also contributes to the elimination of many discrimination, bringing many benefits, including it bridges the gap between men and women in terms of workforce, increases economic diversification and income equality, and importantly, women's economic equality is beneficial to business because companies benefit greatly from their knowledge and experience (Ogato G. S., et al., 2009; Mayoux L., 2010; Belwal R., et al., 2012; Singh J., Yadav P., 2012; Fletschner D., Kenney L., 2014 ).

Nowadays, the development and universal access to information and communication technologies have contributed to their popularity in many environments. It is emphasized in the world literature that ICT covers a wide range of all technologies related to the transmission of information and contributes to the development of a knowledge-based society. It is, therefore, a tool leading to reducing social inequalities and increasing the chances of excluded people, and also allows integrating individual social groups. In a changing environment, continuous acquisition of knowledge is a must, and therefore it is difficult to imagine life today without the use of modern information and communication technologies. Adequate access to women in rural areas to ITC tools is undoubtedly an important strategy that contributes to the social and economic strengthening of women's role and position in rural areas (FAO, 2011). Having access to financial resources enables rural women to purchase the means of production, workforce, and equipment they need to conduct their non-agricultural and agricultural activities (IFAD, 2016; World Bank, 2018; FAO, 2019). 
An important topic is the area of financing opportunities for information and communication technologies that women could use, also in rural areas. Women's access to microfinance within ITC requires special attention, especially regarding strategies to build the right environment for an innovative ICT environment and improvements in funding opportunities for SMEs and start-ups (Bekele D., 2012). Also, women's access to ICT services is limited by economic, legal, institutional, socio-cultural, and even educational barriers (Bishaw A., 2014; Wiggins S., 2014). The European Union, in its strategic documents and numerous resolutions, calls on the Member States to increase support for strengthening the position and role of women in digital and ICT sectors as part of development cooperation and EU external relations and enabling women to set up businesses through a variety of tools, including microfinance programs and support networks (Malgesini R., 2015; Wojcieszak M., 2019). Equal treatment policies can effectively counteract negative phenomena and foster women's education and professional development. Women working parttime in rural areas can contribute to exploiting the opportunities for diversity management.

An important motive for undertaking business activity by women in the countryside is the possibility of creating a new job for themselves. Women want to take up a job other than the duties related to the farm and household. The most common arguments in starting one's own business are the awareness of the attractiveness of villages for tourists and the willingness to show rural areas, e.g. through agritourism, pointing to local traditions and additionally making money on it (Figure 1).
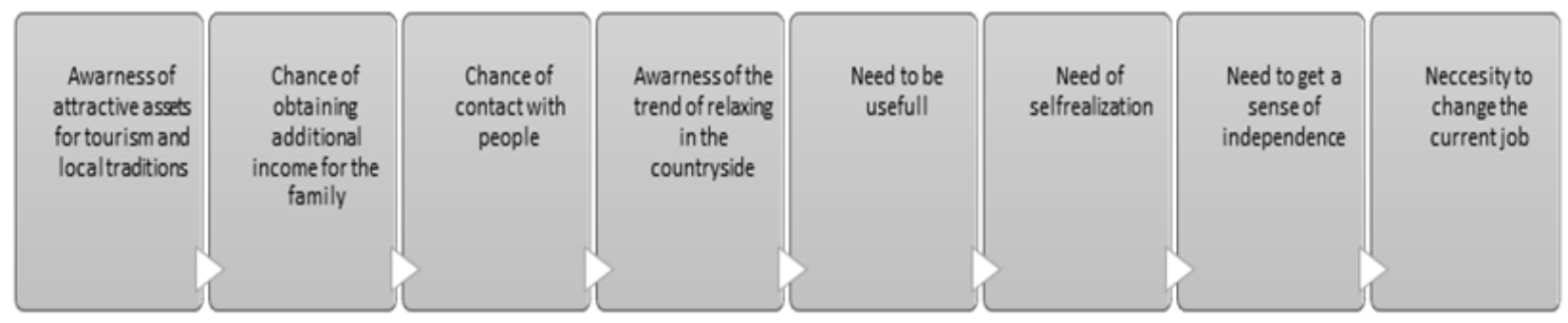

Source: based on (Kubal-Czerwińska M., 2020)

Fig. 1. Motives and factors of starting professional activity by women in rural areas.

As indicated in the figure and according to Kubal-Czerwinska (2020) the following reasons are motivated by women taking up economic activity in rural areas:

- potential increase in farm income (agritourism can be an additional, supplementary, or main source of farm income);

- the ability to start selling organic products, launch organic agricultural production in addition to traditional forms of farming; potential increase in farm income (agritourism can be an additional, supplementary, or main source of farm income);

- the need and opportunity to share the experience of living in the countryside with others (e.g. tourists visiting the farm) and the will to create a positive image of working in the countryside;

- the desire to meet new people;

- achieving satisfaction from working at home;

- achieving satisfaction from working at home;

- pursuing a hobby;

- lifestyle;

- willingness to self-employment, the possibility of employing family members; being for yourself the boss;

- being active when the husband works outside the farm; 
- quitting farm work and creating better conditions for myself work without leaving home;

- willingness to support the rural economy by activating the not most prosperous farms.

The approach to economic development so far has not taken into account the benefits of equitable development for women and men so that it contributes to the emergence of gender inequality and inequality. Therefore, in some fields, efforts are needed to increase the empowerment of women to realize equality of access, participation, benefits, and control between men and women as members of the community. The implementation of entrepreneurship for women, it will provide a variety of quite positive impacts, especially for the economy. But with conditions, training or knowledge about entrepreneurship given must be continuous and gradual so that women will have more time to learn. Besides, there are several things that women must possess to become entrepreneurs, including creative, innovative, risktaking, willingness to make changes, deft, produce efficiently; effective; and productive, fast and precise in making decisions and taking actions, and can calculate quickly and accurately. To realize all these things, starting from the existence of entrepreneurship education for women to the emergence of characteristics that must be possessed, the need for collaboration between the central government, local government, village government, family, the surrounding environment, and the woman herself so that what is desired is achieved. It is also necessary to strengthen management from the internal side of women's entrepreneurial business, which must be carried out by means of: attention and assistance, such as access to production, technology, and marketing which are complemented by strengthening human resources; promotional activities of products produced by women entrepreneurs; more modern machine assistance to help increase the production capacity of women's entrepreneurial businesses. And the most important thing is that there is a need to increase the motivation of the woman herself so that they can be good at entrepreneurship, and get the desired results.

\section{Conclusions}

Interest in enhancing rural women's entrepreneurship is related to the new concept of development of non-urbanized areas adopted in the European Union and defined as a balanced and multifunctional model of rural development.

1) Women in rural areas often have secondary education, few women have completed university studies. Rural women would like to be more valued in the local environment as helping people with good ideas than more educated ones. Most often women in rural areas would like to develop professionally by conducting agricultural activity, a significant number of women thought about combining work in agriculture with non-agricultural activity. The smallest part of women would like to conduct activities related to abandoning agricultural activity.

2) Women in Poland appreciate life in the countryside despite the disadvantages associated with it. However, they work part-time and would like to do business, especially middle-aged women with raised children; Women in rural areas have more and more opportunities to do business. More and more rural women declare that they are interested in starting their enterprise, often of a non-agricultural nature.

3) The problems faced by women living in the countryside can include worse access to the gas and sewage network than in the city, more difficult access to culture and entertainment, fewer opportunities for raising qualifications and education of adults, as well as studying, fewer opportunities for using sports and recreation facilities.

It is particularly important, that the percentage of self-employed women has not approached the percentage of self-employed men in any age group over the past ten years. 


\section{Bibliography}

1. Alonso, N., Trillo, D. (2016). Women, Rural Environment and Entrepreneurship, Procedia - Social and Behavioral Sciences, Vol. 161, 2014, pp. 49-155.

2. Bekele, D. (2012). A Study on Rural Women's Empowerment through Cooperatives: The Case of Saving and Credit Cooperative Societies in Dendi District, West Shoa Zone, Oromia Regional State, Ethiopia. MA Thesis. Ambo: Ambo University. International Journal of Applied Research; 2(8), pp. 367-373

3. Belwal, R., Tamiru, M. and Singh, G. (2012). Microfinance and Sustained Economic Improvement: Women Small- Scale Entrepreneurs in Ethiopia. Journal of International Development, 24(S1), pp. 84-99.

4. Bishaw, A. (2014). The Impact of Education on Rural Women's Participation in Political and Economic Activities. International Journal of Educational Administration and Policy Studies, 6(2), pp. 23-31.

5. Cumber, C.J., Rckerl D.H., Brooks A., Parlinska M., Sawicka J. (2005). The Evolution of Women's Work: Global Women's Issues. International Journal of Case Method Research \& Application, Issue no. 4, pp. 558-568.

6. Damesa, T.E. Ogato, G.S. (2016). Towards Empowering Rural Women through Micro-Finance Assisted Income Generating Activities: The Case of Wesasa Microfinance Institution, Dandi District, Ethiopia Towards Empowering Rural Women through Micro-Finance Assisted Income Generating Activities: The Case of Wesasa Microfinance Institution, Dandi District, Ethiopia. American Journal of Business and Management, Vol. 5, No. 2, 2016, pp.76-84.

7. Eurostat, Farmers in the EU statistics (2017). Data extracted in August 2020.

8. European Parliament resolution of 13 March 2012, https://www.europarl.europa.eu/doceo/document/TA-72012-0069_EN.html, Access: 02.02.2021.

9. FAO (2011). The State of Food and Agriculture. Women in Agriculture: Closing the Gap for Development. Rome, Italy.

10. FAO (2019). Women's Access to Rural Finance: Challenges and Opportunities. Rome, Italy.

11. FOCUS GROUP - CRSG (2012), Raport z badania Sytuacja kobiet w rolnictwie i na obszarach wiejskich. Specyfika, standardy, parytety i oczekiwania (Research Report The situation of women in agriculture and rural areas. Specificity, standards, parities and expectations). Szczecin, Konsorcjum Badawcze. FOCUS GROUP, Centrum Rozwoju Społeczno-Gospodarczego Sp. z o.o., marzec 2012.

12. Fletschner, D., Kenney, L. (2014). Rural Women's Access to Financial Services: Credit, Savings, and Insurance. In Gender in Agriculture. Springer, Netherlands.

13. GUS (2018). Badanie Aktywności Ekonomicznej Ludnosci (Population Economic Activity Survey), Główny Urząd Statystyczny, Warszawa 2019.

14. IFAD (International Fund for Agricultural Development) (2016). Rural Development Report 2016: Fostering inclusive rural transformation. Rome.

15. Istenic, M.C. (2015). Do Rural Development Programs Promote Gender Equality on Farms? The Case of Slovenia, Gender Place, and Culture, Vol. 22, No 5, 2015, pp. 670-684.

16. Kubal-Czerwinska, M. (2020) Motywy Aktywizacji Zawodowej Kobiet Poprzez Agroturystyke (Motives for Professional Activation of Women Through Agritourism). Prace Geograficzne, Wydawnictwo Uniwersytetu Jagiellonskiego, zeszyt 160, 2020, pp. 29-51.

17. Krzyszkowski, J. (2008). Wprowadzenie (Introduction), [In:] J. Krzyszkowski, (eds.) Diagnoza sytuacji społeczno- -zawodowej kobiet wiejskich w Polsce (Diagnosis of the socio-professional situation of rural women in Poland). Warszawa, Ministerstwo Pracy i Polityki Społecznej, p. 11.

18. Krzyzanowska, N. (2013). Femina Oeconomica, czyli o Apoteoretycznej Obecnosci Kobiet w Ekonomii (Femina Oeconomica, or about the Apotheoretical Presence of Women in Economics). Kultura i Edukacja. 4 (97), pp. 171-193.

19. Krzyzanowska, K. (2014). Sytuacja Kobiet na Obszarach Wiejskich i ich Udział w Rynku Pracy (The situation of women in rural areas and their participation in the labor market). Problemy Drobnych Gospodarstw, nr 1, pp. 55-67.

20. Malgesini Rey, G., Cesarini-Sforza, L. (2015). More Visibility to Women in Europe 2020, EAPN Final Report.

21. Mayoux, L. (2010). Reaching and Empowering Women: Towards a Gender Justice Protocol for a Diversified, Inclusive, and Sustainable Financial Sector. Perspectives on Global Development and Technology, 9(3), pp.581600.

22. Michalska, S. (2013). Tradycyjne i Nowe Role Kobiet Wiejskich (Traditional and New Roles of Rural Women). Wies i Rolnictwo, nr 2, pp. 124-139.

23. Mills, M.B. (2016). Gendered Morality Tales: Discourses of Gender, Labor, and Value in Globalizing Asia. The Journal of Development Studies 53(3), pp. 316-330.

24. Moczydlowska, J.M. (2017). Istota i Determinanty Przedsiebiorczosci - Analiza Teoretyczna (The Essence and Determinants of Entrepreneurship - Theoretical Analysis). [In:] M. Makowiec, A. Pietruszka -Ortyl (eds.). Przedsiebiorczosc a Zrodła Przewagi Konkurencyjnej w Gospodarce Opartej na Wiedzy. Wyd. UE w Krakowie, Kraków.

25. Official Journal of the European Union C $296 \mathrm{E}$, https://eur-lex.europa.eu/legal content/EN/TXT/PDF/?uri=OJ:C:2012:296E:FULL\&from=FR, Access: 02.03.2021.

26. Ogato, G.S., Boon, E.K., Subramani, J. (2009). Gender Roles in Crop Production and Management Practices: a Case Study of Three Rural Communities in Ambo District, Ethiopia. Journal of Human Ecology, 27(1), pp.1- 20. 
27. Parlinska, M., Sawicka J. (2004). The Socioeconomic Situation of Women in Rural Areas in Poland. Gender and Economic Opportunities in Poland: Has Transition left Women Behind. The World Bank, Poland, Warsaw Office, pp.111-126.

28. PARP (2011). Przedsiębiorczosc Kobiet w Polsce (Women's Entrepreneurship in Poland). Polska Agencja Rozwoju Przedsiębiorczosci, Warszawa 2011, p.14.

29. PARP (2014). Raport z Badania Global Enterpreneurship Monitor 2014 (Global Entrepreneurship Monitor Report). Global Enterpreneurship Monitor 2014, Polska Agencja Rozwoju Przedsiębiorczości, Warszawa.

30. PARP (2018). Global Entrepreneurship Monitor Poland 2017, Polska Agencja Rozwoju Przedsiębiorczości, Warszawa.

31. Pujol, M.A. (1992). Feminism and Anti-Feminism in Early Economic Thought, Cheltenham 1992.

32. Rural Women in a Changing World, UNITED NATIONS, Division for the Advancement of Women, Department of Economic and Social Affairs, 2008. https://www.un.org/womenwatch/daw/public/Women\%202000\%20\%20Rural\%20Women\%20web\%20English. pdf , Access: 02.02.2021.

33. Sawicka, J. (2005). Rola Kobiet w Aktywizacji i Wielofunkcyjnym Rozwoju Obszarów Wiejskich (The Role of Women in the Activation and Multifunctional Development of Rural Areas). Warszawa, Wydawnictwo SGGW.

34. Sawicka, J. Lagoda J. (2015). Gender and Sustainability in The Economic Development - Equal Chances for Women at The Labor Market Acta Scientiarum Polonorum. Oeconomia, 14 (4), pp.115-125.

35. Singh, J., Yadav, P. (2012). Micro Finance As A Tool For Financial Inclusion \& Reduction Of Poverty. Journal of Business Management \& Social Sciences Research (JBM\&SSR), 1(1), pp.1-12.

36. Sikorska-Wolak, I., Krzyzanowska, K., Zawadka, J. (2018). Edukacja w Turystyce Wiejskiej (Education in Rural Tourism). Wydawnictwo SGGW, Warszawa.

37. Szepelska, A. (2014). Przedsiebiorczosc Kobiet Szansa na Rozwoj Obszarow Wiejskich (Women's Entrepreneurship Chance for Rural Development). Organizacja i Zarządzanie, 62, Zeszysty Naukowe Politechniki Poznanskiej.

38. Varela-Candamio, L., Calvo, N., Novo-Corti, I. (2018). The Role of Public Subsidies for Efficiency and Environmental Adaptation of Farming: A Multi-Layered Business Model Based on Functional Foods and Rural Women, Journal of Cleaner Production, Vol. 183, pp. 555-565.

39. Wiest, K. (2016). Women and Migration in Rural Europe: Labour Markets, Representations and Policies. Basingstoke, Palgrave Macmillan.

40. Wiggins, S. (2014). Rural Non-Farm Economy: Current Understandings, Policy Options, and Future Possibilities. In Hazell, P. B. R. and Rahman, A. (eds). New Directions for Smallholder Agriculture. Oxford: Oxford University Press.

41. Wojcieszak, M. (2019). Female Entrepreneurship in Rural Areas (example of the Wielkopolskie voivodship). Roczniki Naukowe Stworzyszenia Ekonomistów Rolnictwa I Agrobiznesu, XXI(3), pp. 512-521.

42. World Bank (2018). Woman, Business and the Law: Key Findings. Washington DC.

43. Wrzochalska, A. (2013). Kobiety Kierowniczki Gospodarstw Rolnych w UE (Women Farm Managers in the EU). Program Wieloletni, IERiGŻ-PIB, Warszawa.

44. Yasaswini, Y., Tharaka, U., Bhagavanulu D. (2017). Socio-Economic Conditions of Rural Women - a Case Study. International Journal of Research and Scientific Innovation, 4(8), pp. 52-54. 